\title{
STERNAL WOUND INFECTION AFTER HEART OPERATIONS IN PEDIATRIC PATIENTS ASSOCIATED WITH NASAL CARRIAGE OF STAPHYLOCOCCUS AUREUS
}

Christian Ruef, $\mathrm{MD}^{\mathrm{a}}$

Sergio Fanconi, $\mathrm{MD}^{\mathrm{b}}$

David Nadal, $\mathrm{MD}^{\mathrm{c}}$
A cluster of six pediatric cases of deep-seated Staphylococcus aureus infection after heart operations prompted us to perform molecular typing of the $S$. aureus isolates by pulsed-field gel electrophoresis. This revealed the presence of genotypically distinct isolates in four of the six patients. Isolates of two patients were genotypically identical. All patients carried $S$. aureus in the anterior nares. In each patient, the banding pattern of deoxyribonucleic acid in these isolates was indistinguishable from that in strains isolated from blood or wound cultures. Molecular typing with pulsed-field gel electrophoresis ruled out nosocomial transmission of $S$. aureus between four patients; at the same time, it provided evidence for an association between nasal colonization and postoperative wound infection. Epidemiologic investigation of potential links between two patients with identical isolates did not provide any evidence for nosocomial transmission of $S$. aureus between these patients. Because nasal colonization with $S$. aureus may be a risk factor for surgical wound infection in pediatric patients undergoing heart operations, preoperative decolonization appears to be warranted. (J Thorac Cardiovasc Surg 1996;112:681-6)
$T_{\text {hes }}^{\text {he }}$ he spectrum of sternal wound infections after heart operations ranges from superficial infections to severe, deep-seated infections. ${ }^{1}$ The latter usually necessitate both surgical intervention and prolonged parenteral antibiotic therapy. Because of the potential seriousness of this complication, measures to reduce the risk of sternal wound infection are important. These include preoperative antibiotic prophylaxis, sterile surgical technique, and skin disinfection at the surgical site.

A cluster of six pediatric cases of deep-seated Staphylococcus aureus infection after heart operations prompted us to perform molecular typing of the $S$. aureus isolates cultured from blood and from

From the Division of Infectious Diseases and Hospital Epidemiology, ${ }^{a}$ University Hospital Zurich, and the Intensive Care Unit $^{b}$ and Infectious Diseases Unit, ${ }^{c}$ University Children's Hospital, Zurich, Switzerland.

Supported in part by grant no. 32-40884.94 from the Swiss National Foundation for Scientific Research to C.R.

Received for publication Nov. 28, 1995; revisions requested Jan. 23, 1996; revisions received Feb. 14, 1996; accepted for publication Feb. 15, 1996.

Address for reprints: David Nadal, MD, Infectious Diseases Unit, University Children's Hospital, Steinwiesstrasse 75, 8032 Zürich, Switzerland.

Copyright (C) 1996 by Mosby-Year Book, Inc.

$0022-5223 / 96 \$ 5.00+0 \quad \mathbf{1 2 / 1 / 7 2 8 9 8}$ swabs from the sternal wound, various skin folds, throat, and nares. Surprisingly, our investigations (which were carried out for hospital infection control reasons) revealed nasal carriage of $S$. aureus with genotypes identical to those of the respective isolates from blood and sternal wound in all patients. These results and the recently documented association of $S$. aureus nasal carriage with an increased risk of sternal wound infection ${ }^{2}$ raise a question regarding whether preoperative nasal decolonization is warranted as a prophylactic measure for all patients undergoing sternotomy.

\section{Patients and methods}

Patients. Patients with clinical evidence of $S$. aureus sternal wound infection after heart operations at the University Hospital of Zurich between January and May 1995 were included in this report. On suspicion of sternal wound infection, swabs or specimens of clinically relevant body sites or body fluids, as well as swab samples from nares, throat, axilla, and inguinal folds, were obtained for bacterial culture.

Microbiologic analysis. $S$. aureus was isolated and susceptibility testing was performed with standard microbiologic procedures.

Molecular typing. Pulsed-field gel electrophoresis (PFGE) was performed essentially as described by Back and coworkers, ${ }^{3}$ with some minor modifications as follows: After overnight growth of $S$. aureus isolates in laked blood broth, the bacteria were centrifuged to form pellets, 
Table I. Synopsis of six children with congenital heart disease and sternum osteomyelitis after cardiac operations

\begin{tabular}{|c|c|c|c|c|c|c|c|}
\hline Patient & Sex & Age & Undertying disease & Surgical procedure & $\begin{array}{c}\text { Bypass time } \\
\text { (min) }\end{array}$ & $\begin{array}{c}\text { Postoperative } \\
\text { course }\end{array}$ & $\begin{array}{l}\text { Signs of sternal wound } \\
\text { infection }\end{array}$ \\
\hline 1 & Boy & $\begin{array}{l}16 \\
\text { mo }\end{array}$ & $\begin{array}{l}\text { Transposition of great } \\
\text { arteries, pulmonary } \\
\text { atresia, mitral atre- } \\
\text { sia, atrial septal } \\
\text { defect, Blalock- } \\
\text { Taussig shunt }\end{array}$ & $\begin{array}{l}\text { Hemi-Fontan, liga- } \\
\text { tion of Blalock- } \\
\text { Taussig shunt }\end{array}$ & 140 & $\begin{array}{l}\text { Low-output syn- } \\
\text { drome, supraven- } \\
\text { tricular arrhyth- } \\
\text { mias, thrombosis } \\
\text { of femoral artery }\end{array}$ & $\begin{array}{l}\text { Day } 24 \text { after operation: } \\
\text { fever, tachypnea and } \\
\text { tachycardia, local } \\
\text { swelling, hyperemia, } \\
\text { and tenderness }\end{array}$ \\
\hline 2 & Girl & $\begin{array}{l}14 \\
\text { mo }\end{array}$ & $\begin{array}{l}\text { Tetralogy of Fallot, } \\
\text { Down syndrome }\end{array}$ & $\begin{array}{l}\text { Complete surgical } \\
\text { repair }\end{array}$ & 181 & $\begin{array}{l}\text { Low-output syn- } \\
\text { drome }\end{array}$ & $\begin{array}{l}\text { Day } 20 \text { after operation: } \\
\text { fever; local swelling, } \\
\text { hyperemia, and ten- } \\
\text { derness }\end{array}$ \\
\hline 3 & Boy & $9 \mathrm{yr}$ & $\begin{array}{l}\text { Congenital aortic } \\
\text { valve stenosis, aor- } \\
\text { tic insufficiency } \\
\text { (surgical valvulo- } \\
\text { plasty at } 6 \text { months) }\end{array}$ & $\begin{array}{l}\text { Ross procedure } \\
\text { with pulmonary } \\
\text { homograft }\end{array}$ & 89 & $\begin{array}{l}\text { Rethoracotomy for } \\
\text { major bleeding on } \\
\text { day } 1 \text {; sternum } \\
\text { closure on day } 2 \text {; } \\
\text { surgical removal } \\
\text { of wound drain- } \\
\text { age on day } 5 \text {; re- } \\
\text { current atelectasis } \\
\text { of left lung }\end{array}$ & $\begin{array}{l}\text { Day } 4 \text { after operation: } \\
\text { fever, purulent dis- } \\
\text { charge from sternal } \\
\text { wound }\end{array}$ \\
\hline 4 & Girl & $\begin{array}{l}5 \\
\text { mo }\end{array}$ & $\begin{array}{l}\text { Tricuspid atresia, } \\
\text { ASD, PDA; Bla- } \\
\text { lock-Taussig shunt } \\
\text { at } 1 \text { day }\end{array}$ & $\begin{array}{l}\text { Blalock-Taussig } \\
\text { shunt }\end{array}$ & 0 & $\begin{array}{l}\text { Recurrent atelecta- } \\
\text { sis, pleural effu- } \\
\text { sion; cardiac fail- } \\
\text { ure }\end{array}$ & $\begin{array}{l}\text { Day } 24 \text { after operation: } \\
\text { fever, drainage from } \\
\text { sternal wound }\end{array}$ \\
\hline 5 & Boy & $4 \mathrm{yr}$ & $\begin{array}{l}\text { VSD repair at } 3 \\
\text { months; pulmonary } \\
\text { stenosis }\end{array}$ & $\begin{array}{l}\text { Resection of pul- } \\
\text { monary stenosis, } \\
\text { reconstruction } \\
\text { of pulmonary } \\
\text { outflow tract }\end{array}$ & 53 & Uneventful & $\begin{array}{l}\text { Day } 21 \text { after operation: } \\
\text { fever, local swelling, } \\
\text { hyperemia, tender- } \\
\text { ness }\end{array}$ \\
\hline 6 & Boy & $\begin{array}{l}1 \\
\text { mo }\end{array}$ & $\begin{array}{l}\text { Interrupted aortic } \\
\text { arch, VSD, PDA }\end{array}$ & $\begin{array}{l}\text { Resection of co- } \\
\text { arctation, end- } \\
\text { to-side anasto- } \\
\text { mosis, VSD } \\
\text { patch closure, } \\
\text { PDA ligation }\end{array}$ & 100 & $\begin{array}{l}\text { Low cardiac output, } \\
\text { seizures, renal } \\
\text { failure }\end{array}$ & $\begin{array}{l}\text { Day } 18 \text { after operation: } \\
\text { fever, local swelling, } \\
\text { hyperemia }\end{array}$ \\
\hline
\end{tabular}

$A S D$, Atrial septal defect; $P D A$, patent ductus arteriosus; $V S D$, ventricular septal defect.

which were resuspended and mixed with $2 \%$ low-melt agarose and lysostaphin at $45^{\circ} \mathrm{C}$. Agarose plugs were incubated with lysozyme, followed by digestion of bacterial deoxyribonucleic acid with SmaI.

PFGE was performed with a $1 \%$ agarose gel in $0.5 \times$ Tris-boric acid-ethylenediaminetetraacetic acid buffer at $12^{\circ} \mathrm{C}$. Run conditions of the CHEF DR III system (Bio-Rad, Glattbrugg, Switzerland) were 5 volts at an included angle of 120 degrees from an initial switch time of 5 seconds to a final switch time of 60 seconds. The run was terminated after 24 hours, and the gel was photographed after staining with ethidium bromide. Banding patterns were compared visually. According to criteria published by Tenover and associates, ${ }^{4}$ strains were considered genotypically indistinguishable if their restriction patterns had the same number of bands and the same apparent size.

\section{Results}

Clinical course. During the course of 5 months, we observed six pediatric patients with deep-seated sternal wound infections. A synopsis of the underlying diseases, surgical procedures, clinical presentation, microbiologic assessment, antibiotic regimens, and outcomes is given in Table I. The patients received 25 $\mathrm{mg} / \mathrm{kg}$ intravenous cefazolin 30 to 60 minutes before operation. Although most patients had uneventful surgical courses, patient 3 had major venous bleeding at the surgical site and required packing of the wound and secondary closure of the sternum. The sternum of patient 6 was closed on the first postoperative day because of low cardiac output. 


\begin{tabular}{|c|c|c|}
\hline $\begin{array}{c}\text { Bacterial } \\
\text { isolates }\end{array}$ & Treatment & Outcome \\
\hline $\begin{array}{l}\text { S. aureus cultured from } \\
\text { blood and swabs } \\
\text { from sternal wound, } \\
\text { throat, and nares }\end{array}$ & $\begin{array}{l}\text { Surgical drainage, intra- } \\
\text { venous vancomycin } \\
\text { and gentamicin for } 2 \\
\text { days, then switch to } \\
\text { intravenous fluclox- } \\
\text { acillin for } 4 \text { weeks }\end{array}$ & Cured \\
\hline $\begin{array}{l}\text { S. aureus cultured from } \\
\text { blood and swabs } \\
\text { from sternal wound } \\
\text { and nares }\end{array}$ & $\begin{array}{l}\text { Surgical drainage, intra- } \\
\text { venous flucloxacillin } \\
\text { for } 4 \text { weeks }\end{array}$ & Cured \\
\hline $\begin{array}{l}\text { S. aureus cultured from } \\
\text { blood, sternal } \\
\text { wound, axilla, throat, } \\
\text { inguinal fold, and } \\
\text { nares }\end{array}$ & $\begin{array}{l}\text { Surgical drainage, genta- } \\
\text { micin implants, intra- } \\
\text { venous flucloxacillin } \\
\text { for } 4 \text { weeks }\end{array}$ & Cured \\
\hline $\begin{array}{l}\text { S. aureus cultured from } \\
\text { sternal wound, ingui- } \\
\text { nal fold, throat, and } \\
\text { nares }\end{array}$ & $\begin{array}{l}\text { Intravenous flucloxacil- } \\
\text { lin for four weeks; } \\
\text { intermittent amoxicil- } \\
\text { lin-clavulanic acid }\end{array}$ & $\begin{array}{r}\text { Died } 2 \text { weeks } \\
\text { later of car- } \\
\text { diac failure }\end{array}$ \\
\hline $\begin{array}{l}\text { S. aureus cultured from } \\
\text { sternal wound and } \\
\text { nares }\end{array}$ & $\begin{array}{l}\text { Surgical drainage; intra- } \\
\text { venous flucloxacillin } \\
\text { for } 2 \text { weeks }\end{array}$ & Cured \\
\hline $\begin{array}{l}\text { S. aureus cultured from } \\
\text { sternal wound, ve- } \\
\text { nous catheter site, } \\
\text { and nares }\end{array}$ & $\begin{array}{l}\text { Surgical drainage; } \\
\text { amoxicillin-clavulanic } \\
\text { acid ( } 4 \text { weeks) and } \\
\text { intravenous aminogly- } \\
\text { coside ( } 2 \text { weeks), gen- } \\
\text { tamicin implants }\end{array}$ & \\
\hline
\end{tabular}

Signs and symptoms suggesting sternal wound infection became apparent between 4 and 24 days after operation (Table I). All six patients were febrile up to a temperature of $41^{\circ} \mathrm{C}$, had leukocytosis with leukocyte counts between 19,600 and $24,000 \mathrm{cells} / \mu \mathrm{l}$, and had elevated levels of C-reactive protein ranging from 40 to $175 \mathrm{mg} / 1$ (normal $<5 \mathrm{mg} / 1$ ). In all six cases, $S$. aureus was recovered from the sternal wound. Three patients had blood cultures positive for this organism. Surgical revision of the sternum and a 4-week course of intravenous flucloxacillin $\left(100 \mathrm{mg} \cdot \mathrm{kg}^{-1} \cdot \mathrm{day}^{-1}\right)$ or amoxicillin-clavulanic acid in combination with an aminoglycoside resulted in complete recovery in five cases. One patient died of cardiac failure 2 weeks after cessation of antibiotic therapy, without evidence for recurrence or persistence of sternal wound infection. During the same 5-month period 60 surgical repairs with bypass were performed in pediatric patients. There was no correlation between bypass time and occurrence of sternal wound infection (data not shown).

Recovery of $S$. aureus. The results of bacterial cultures done on suspicion of sternal wound infection are presented in Table II. S. aureus was recovered from the sternal wound and nares in all six patients. Furthermore, $S$. aureus was isolated from throat swabs in patients 1,3 , and 4 and also from the axilla or inguinal fold in patients 3 and 4 (Tables I and II). The susceptibility patterns of the isolates of five of the six patients were identical. The isolates from patient 6 were sensitive to all antibiotics tested, including ampicillin. All other isolates were resistant to ampicillin but uniformly sensitive to oxacillin, flucloxacillin, cefazoline, gentamicin, amikacin, vancomycin, teicoplanin, and mupirocin.

Genotype pattern. Molecular genotyping by PFGE revealed that the $S$. aureus isolates from sternal wound and nares were identical for each patient but differed among patients, except for isolates from patients 2 and 4, which showed indistinguishable banding patterns (Fig. 1). As shown in Fig. 1, S. aureus isolated from blood (patients 1 through 3), skin (patient 4), and entry site of a venous catheter (patient 6) were genotypically identical with the strains isolated from the sternal wounds and nares of individual patients. On the other hand, the throat isolate of patient 1 was genotypically distinct from the other isolates from that patient (not shown).

Epidemiologic investigation of possible modes of transmission between patients 2 and 4. Although the same two members of the surgical department performed the surgical procedures on both patients, there was an interval of more than 3 months between the two operations. No common source of the $S$. aureus strain isolated from both patients was apparent.

\section{Discussion}

We observed a cluster of deep-seated sternal wound infections after heart operations in pediatric patients. The infections were significant in all six patients, resulting in bacteremia in three patients and necessitating surgical drainage in all but one. Preoperative antibiotic prophylaxis was used in all cases. Despite the fact that the infections occurred over a period of less than 5 months, the results of molecular typing by PFGE ruled out nosocomial transmission of $S$. aureus between patients in four of 
Table II. Recovery of S. aureus in patients with sternal wound infection after heart operations

\begin{tabular}{lllllll}
\hline \multicolumn{1}{c}{ Site } & \multicolumn{5}{c}{ Bacterial cultures for S. aureus } \\
\cline { 2 - 7 } & Patient 1 & Patient 2 & Patient 3 & Patient 4 & Patient 5 & Patient 6 \\
\hline Blood & Positive & Positive & Positive & Negative & Negative & Negative \\
Sternal wound & Positive & Positive & Positive & Positive & Positive & Positive \\
Nares & Positive & Positive & Positive & Positive & Positive & Positive \\
Throat & Positive* & Negative & Positive & Positive & Negative & ND \\
Axilla & Negative & Negative & Positive & Negative & Negative & Negative \\
Inguinal fold & Negative & Negative & Positive & Positive & Negative & Negative \\
\hline
\end{tabular}

Patient 6 had $S$. aureus isolated at insertion site of venous catheter. ND, Not done.

${ }^{*}$ Genotype distinct from genotype of the other isolates from the same patient.

the six cases. Each of these four patients was colonized and infected with a distinct isolate (Fig. 1).

Two patients had genotypically identical isolates, but nosocomial transmission between these two patients is unlikely because they had no contact and were hospitalized during two separate months. Transmission originating from a common source, such as a carrier of $S$. aureus is an obvious concern. Our epidemiologic investigation discovered that two members of the health care team were involved in surgery and perioperative care in both cases. Both persons perform surgical procedures regularly and have not been found to be nasal carriers of this particular genotype of $S$. aureus; however, transmission from ancillary staff cannot be completely ruled out because medical records list only professionals directly involved in anesthesia and surgery. So far no additional cases of wound infection caused by this genotype have been detected. Because nasal cultures were not routinely obtained from all patients undergoing heart operations, we cannot exclude the possibility that additional patients who did not acquire infectious complications were also colonized with one or more of these strains. Colonization of the two patients with this particular strain during the preoperative stay in the Children's Hospital must also be considered.

An intriguing aspect of this case series is the fact that nasal colonization by $S$. aureus with a genotype identical to the genotype of isolates recovered from the sternal wound, and in some cases also blood and other sites, was present in all cases. At this point, it remains speculative whether nasal colonization was present before onset of infection or whether nasal colonization was the result of secondary spread from an infected site. Nonetheless, the role of $S$. aureus nasal colonization as a risk factor for the development of sternal wound infection after heart operations has recently been reported. ${ }^{2}$ During a 3-year period, 1980 patients undergoing elective heart operations were screened for nasal carriage of $S$. aureus before operation. Nasal carriage of $S$. aureus was significantly associated with the development of wound infection (odds ratio 9.6, confidence interval 3.9 to 23.7) compared with a control population without surgical wound infection. The phage typings of the available preoperative and postoperative isolates were identical. The other relevant risk factor in this study was insulin-dependent diabetes mellitus. ${ }^{2}$ A similar prospective study is currently planned to investigate whether preoperative screening and decolonization of pediatric patients would result in a reduced rate of postoperative infections by $S$. aureus. This study will also examine possible risk factors for nasal colonization, such as prolonged preoperative hospital stay, prolonged intubation, stay in intensive care unit, antibiotic use, and contact with colonized health care workers.

Similar linkage of nasal carriage of $S$. aureus with postoperative wound infection was demonstrated by two studies published in 1959. Williams and coworkers, ${ }^{5}$ reporting on 722 patients, observed that the wound infection rate was $2 \%$ among patients without nasal carriage of $S$. aureus and $7.1 \%$ among carriers of $S$. aureus. Although this study did not specify the types of surgical procedures performed, ${ }^{5}$ Weinstein $^{6}$ reported on 125 procedures, 101 of which involved the lung. Again, the wound infection rate was lower $(1.2 \%)$ in the group with negative bacterial cultures of the nose than in the group with positive bacterial cultures $(11.7 \%)$. Comparison of bacterial isolates by phage typing showed that the strains recovered from the infected wound and from the nares were identical. ${ }^{6}$ The rate of nasal carriage was $34 \%$ in Weinstein's study ${ }^{6}$ and $38 \%$ in the study published by Williams and coworkers, ${ }^{5}$ who in addition demonstrated that nasal carriage rate increased with prolongation of the preoperative hospital stay. 
A more recent study in a surgical intensive care unit also demonstrated that nasal colonization by $S$. aureus was associated with a higher rate of infection caused by this organism. ${ }^{7}$ The observation that the systematic use of mupirocin nasal ointment in all patients admitted to the unit was temporarily associated with a significant reduction in the incidence of $S$. aureus infections lends further support to the postulate that nasal colonization precedes rather than follows colonization or infection at other body sites. ${ }^{7}$ The indiscriminate use of mupirocin in all patients admitted to intensive care units cannot be recommended, however, because such a practice might facilitate the development of resistance. ${ }^{8}$

Nasal colonization as a risk factor for infection at a distant site is not unique to surgery, however. Increased rates of infection in nasal carriers of $S$. aureus have been reported in patients infected with human immunodeficiency virus, ${ }^{9}$ users of illicit intravenous drugs, ${ }^{10}$ persons with diabetes, ${ }^{11}$ and patients undergoing hemodialysis ${ }^{12-14}$ or peritoneal dialysis. ${ }^{15}$

In patients undergoing hemodialysis, attempts at nasal decolonization by topical decontamination with mupirocin have been successful. ${ }^{13}$ Mupirocin has been shown to effectively eradicate nasal carriage of methicillin-resistant $S$. aureus in most carriers. ${ }^{16}$ It is well tolerated and does not cause any significant side effects. ${ }^{17}$ The development of resistance in settings where this compound is used widely, however, may limit its usefulness in the future. ${ }^{18}$

To avoid the spread of mupirocin resistance as a result of wide use of this compound, the clinical indications for use should be clearly defined. A recent study by Kluytmans, Vandenbergh, and Verbrugh $^{19}$ indicates that mupirocin treatment may indeed result in a reduction of the rate of postoperative wound infections after heart operations. Conceivably, preoperative screening of patients followed by mupirocin treatment of nasal carriers of $S$. aureus could be a useful strategy to reduce surgical wound infections. Alternatively, certain risk groups could be targeted for screening, including patients with diabetes or renal insufficiency and pediatric patients with congenital heart disease. Patients in the last group typically have spent a relatively large amount of time in hospitals and other medical facilities, which may further increase the risk for nasal colonization. ${ }^{5}$

Finally, isolates from five of the six patients reported on here had identical susceptibility pat-

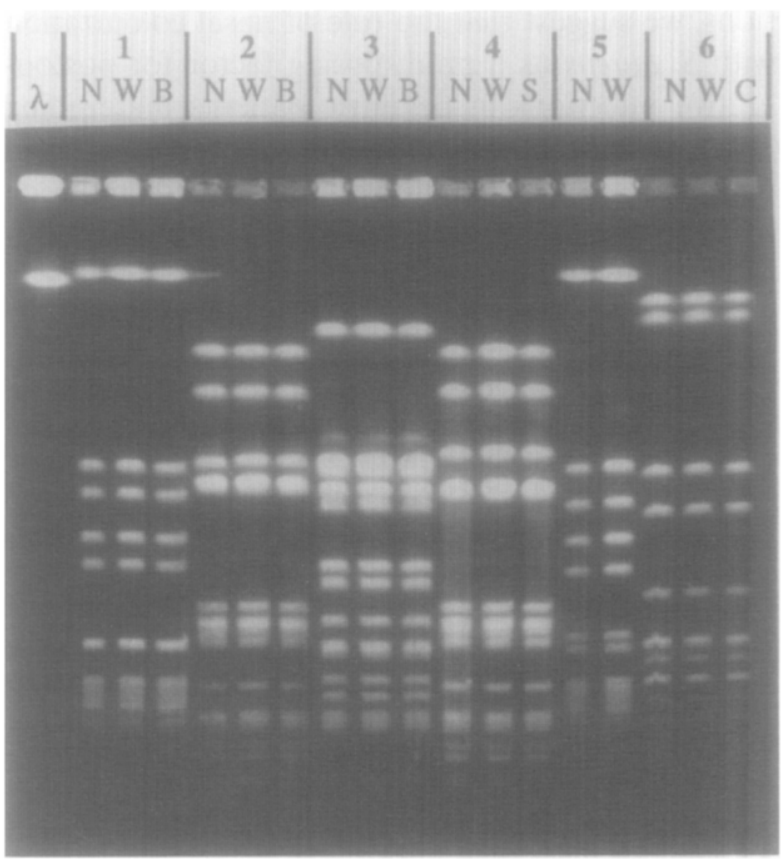

Fig. 1. Deoxyribonucleic acid fingerprints obtained for Staphylococcus aureus strains by PFGE of SmaI-digested bacterial deoxyribonucleic acid. Lowercase lambda $(\lambda)$ indicates molecular size markers. Isolates from patients 1 through 6 are labeled according to source: nares, $N$; sternal wound, $W$; blood culture $B$; skin $S$; venous catheter site, $C$.

terns. They were all resistant to ampicillin but uniformly sensitive to all other antibiotics tested, including mupirocin. This fact also underlines the importance of molecular typing methods to distinguish among isolates and to determine whether further epidemiologic investigations focusing on nosocomial transmission are needed. This report shows that rapid investigation with molecular epidemiologic tools allows the clinician to rule out nosocomial transmission of $S$. aureus between patients. A time-consuming epidemiologic investigation of possible risk factors and modes of transmission was thus avoided in four cases, and efforts could be concentrated on the investigation of possible links between the other two patients. In addition, the discriminatory power of genetic fingerprinting clearly established the distinctness of isolates from individual patients, as well as the identity of various isolates recovered from single patients. This information formed the basis for the hypothesis that nasal colonization of pediatric patients undergoing heart operations may be a risk factor for the development of surgical site infection. On the basis of our observa- 
tions, we suggest that the role of nasal colonization with $S$. aureus as a predisposing factor for postoperative infections in pediatric patients undergoing heart operations should be evaluated in a prospective study and that this study should include research into the effects of mupirocin on the rate of postoperative infections in colonized patients.

We are indebted to the surgeons of the Clinic for Cardiovascular Surgery at the University Hospital of Zurich, under the leadership of Professor M. Turina, and to Ms. Silvia Fröhlich and Ms. Claudia Vanoli for technical assistance in identification and molecular typing of the isolates.

\section{REFERENCES}

1. Kluytmans JA, Mouton JW, Maat AP, Manders MA, Michel MF, Wagenvoort JH. Surveillance of postoperative infections in thoracic surgery. $\mathbf{J}$ Hosp Infect 1994;27:139-47.

2. Kluytmans JA, Mouton JW, Ijzerman EP, VandenbrouckeGrauls CM, Maat AW, Wagenvoort JH, et al. Nasal carriage of Staphylococcus aureus as a major risk factor for wound infections after cardiac surgery. J Infect Dis 1995;171:216-9.

3. Back NA, Linnemann CC, Pfaller MA, Staneck JL, Morthland V. Recurrent epidemics caused by a single strain of erythromycin-resistant Staphylococcus aureus: the importance of molecular epidemiology. JAMA 1993;270:1329-33.

4. Tenover FC, Arbeit RD, Goering RV, Mickelsen PA, Murray $\mathrm{BE}$, Persing $\mathrm{DH}$, et al. Interpreting chromosomal DNA restriction patterns produced by pulsed-field gel electrophoresis: criteria for bacterial strain typing. J Clin Microbiol 1995;33:2233-9.

5. Williams REO, Jevons MP, Shooter RA, Hunter CJW, Girling JA, Griffiths JD, et al. Nasal staphylococci and sepsis in hospital patients. BMJ 1959;2:658-63.

6. Weinstein HJ. The relation between the nasal-staphylococcal-carrier state and the incidence of postoperative complications. N Engl J Med 1959;260:1303-10.

7. Talon D, Rouget C, Caillenx V, Bailly P, Thouverez M, Barale F, et al. Nasal carriage of Staphylococcus aureus and cross-contamination in a surgical intensive care unit: efficacy of mupirocin ointment. J Hosp Infect 1995;30:39-49.

8. Hudson I. The efficacy of intranasal mupirocin in the preven- tion of staphylococcal infections: a review of recent experience. J Hosp Infect 1994;27:81-98.

9. Weinke T, Schiller R, Fehrenbach FJ, Pohle HD. Association between Staphylococcus aureus nasopharyngeal colonization and septicemia in patients infected with the human immunodeficiency virus. Eur J Clin Microbiol Infect Dis 1992;11: 985-9.

10. Tuazon CU, Sheagren JN. Increased rate of carriage of Staphylococcus aureus among narcotic addicts. J Infect Dis 1974;129:725-7.

11. Smith JA, O'Connor JJ, Willis AT. Nasal carriage of Staphylococcus aureus in diabetes mellitus. Lancet 1966;2:776-7.

12. Yu VL, Goetz A, Wagener M, Smith PB, Rihs JD, Hanchett $\mathrm{J}$, et al. Staphylococcus aureus nasal carriage and infection in patients on hemodialysis: efficacy of antibiotic prophylaxis. N Engl J Med 1986;315:91-6.

13. Boelaert JR, Van Landuyt HW, Godard CA, Daneels RF, Schurgers ML, Matthys EG, et al. Nasal mupirocin ointment decreases the incidence of Staphylococcus aureus bacteremias in haemodialysis patients. Nephrol Dial Transplant 1993;8: 235-9.

14. Chow JW, Yu VL. Staphylococcus aureus nasal carriage in hemodialysis patients: its role in infection and approaches to prophylaxis. Arch Intern Med 1989;149:1258-62.

15. Luzar MA, Coles GA, Faller B, Slingeneyer A, Dah GD, Briat C, et al. Staphylococcus aureus nasal carriage and infection in patients on continuous ambulatory peritoneal dialysis. N Engl J Med 1990;322:505-9.

16. Reagan DR, Doebbeling BN, Pfaller MA, Sheetz CT, Houston AK, Hollis RJ, et al. Elimination of coincident Staphylococcus aureus nasal and hand carriage with intranasal application of mupirocin calcium ointment. Ann Intern Med 1991;114:101-6

17. Doebbeling $B N$, Breneman $\mathrm{DL}$, Neu HC, Aly R, Yangco BG, Holley HP Jr, et al. Elimination of Staphylococcus aureus nasal carriage in health care workers: analysis of six clinical trials with calcium mupirocin ointment-The Mupirocin Collaborative Study Group. Clin Infect Dis 1993; 17:466-74.

18. Cookson BD. Mupirocin resistance in staphylococci. J Antimicrob Chemother 1990;25:497-503.

19. Kluytmans JA, Vandenbergh MF, Verbrugh HA. Costefficacy of mupirocin prophylaxis in thoracic surgery (abstract S72). Infect Control Hosp Epidemiol 1995; 16(Suppl):P33. 